\title{
New Zealand - China FTA: Trade Growth amid Social Changes
}

\section{Joanna Siekiera*}

Siekiera, J. (2021). New Zealand - China FTA: Trade Growth amid Social Changes. Lex Portus, 7(4), 7-27. https://doi.org/10.26886/2524-101X.7.4.2021.1

*Doctor of Public Policy, International Lawyer at the Faculty of Law, member of the Bergen Pacific Studies Research Group at the University of Bergen (Magnus Lagabøtesplass 1, 5020 Bergen, Norway)

https://orcid.org/0000-0003-0125-9121

(c) 12 This work is licensed under a Creative Commons AttributionNonCommercialShareAlike 4.0 International License

\section{ABSTRACT}

Many legal and business mechanisms were introduced by the government in Wellington in order to enable trade practices of the Chinese partners. Asian immigrants to New Zealand do fill the real gap in the small labour market of Aotearoa by providing highly qualified and hard-working workers. As a consequence, almost every area of New Zealand's social and economic life is subject to changes. This phenomenon of such new and unexpected demographic situation has been portrayed by coining a new name for the country a few years ago - Niu Chiland. In fact, the only ethnic group in New Zealand that increases every year is the Chinese. Although, according to official data, there are only $5 \%$ of Chinese in the society of almost 5 million people, the real data is much larger. In Auckland, the country's largest city and its business capital, having population of over 1.5 million, every fourth resident is of Chinese origin. The 
Free Trade Agreement turned out to be a breakthrough, as Wellington was the first capital among developed Western countries that decided to legally bind itself with the People's Republic of China in 2008. In 2021, China and New Zealand signed the Protocol to amend the New Zealand-China agreement and to add some previously not taken into consideration spheres, such as e-commerce and environment. While New Zealand economy clearly shows benefits of trade with China, and anyhow sees any potential negative effects, like political dependence from this communist state not respecting human rights, between the politicians in Canberra and Beijing there continue to escalate tensions. Australia, contrary to New Zealand, is trying to contain Chinese imperialist's appetite and stop Beijing before launching own sphere of interest in the Pacific region.

The key words: New Zealand, China, trade, international trade, Chinese migration, Chinese minority, Pacific, South Pacific.

\section{Introduction}

The Chinese minority is an increasingly large ethnic group in New Zealand. According to the official statistics made by the New Zealand Statistics Office, Chinese migrants and people claiming Chinese origin make up to $5 \%$ of almost 5 million New Zealand population. However, when we look at the largest city in New Zealand, being the trade capital of the country - Auckland - there are more than $25 \%$ of Chinese. This article tends therefore to describe the economic ties between the two nations representing slightly different legal, political and cultural background. Yet, it will not be possible without analysing and somehow predicting the potential, indeed huge, social change within the New Zealand nation. The New Zealand culture was in fact always embedded in the Western culture, along with its closest partner, both politically and economically, "bigger brother" - Australia.

As the author of this article used to live in New Zealand ${ }^{1}$, she herself has witnessed many legal and business mechanisms which

1 On the occasion of first the $\mathrm{PhD}$ visiting in four faculties of law in New Zealand (University of Auckland; University of Canterbury; University of Waikato; Victoria University of Wellington) in the first half of 2015 and then the $\mathrm{PhD}$ studies at the Victoria University of Wellington in 2015-2016. 
were introduced by the government in Wellington in order to enable trade practises for the Chinese partners. Asian immigrants do fill the real gap in the small labour market of Aotearoa ${ }^{1}$ by providing highly qualified and hard-working workers. As a consequence, almost every area of New Zealand's social and economic life is subject to changes. This phenomenon of the new and unexpected demographic situation has been portrayed by coining a new name for the country a few years ago - Niu Chiland².

\section{Methodology}

In the article mainly the legal methodology was used in its international law domain. The written sources were used, with some exceptions of oral interviews made by the author. Research objectives were to portray the bilateral economic relations, but also to present them at the social changes background. Therefore, the chosen methodology had to cover two sources of knowledge legal arrangements issued, signed and ratified by the two states, as well as pure economic data presented by the administrative organs, such as the New Zealand Ministry of Foreign Affairs and Trade and the New Zealand Statistics Office. As nowadays many useful information presented by politicians and gathered by journalists are posted online, the very fruitful sources turned out to be websites of public institutions, private media and, last but not least, business facilitating organizations. Finally, the author's herself staying in New Zealand was the truth motivation and unique opportunity to gather ideas, thoughts presented by New Zealanders, both ordinary citizens and academic professors. As the article was not meant to be economic but be written in the domain of international relations

1 Second official name of the state in the Maori language, which means "land of the long white cloud".

2 This term in unofficial name, used by private people, thus one cannot find it in any public and science publications. Yet, it does show the approach of ordinary New Zealanders about the social changes in their country. 
using international law tools, the author decides to limit the method of any further statistics, economic graphs or detailed data.

\section{New Zealand as a Welfare State and a Strong Regional Actor}

Aotearoa is perceived as a welfare state, a regional role model, and finally a country open to other nationalities, religions, or ways of life. As the regional pattern of prosperity for the poor, underdeveloped Pacific Island countries and territories (PICT), New Zealand is the perfect example of how, from a subordinate colony, and then the British dominion, to become one of the most developed economies in the world. The welfare state policy implemented by the government in Wellington has introduced a number of appropriate institutional and legal mechanisms, primarily in the field of international economics. The awareness of New Zealand society is also high, which translates into active participation of citizens in public life and efforts to obtain better, that is more convenient and less expensive, living and working conditions. New Zealand's presence in the region, and its regional policy, is noticeable in launching numerous government programs and participating in many local international organizations, both governmental (IGO) and non-governmental (NGO) ones. Roughly there are there are over 30 regional organizations, and over a dozen of less formalized groupings of states (Siekiera, 2020).

New Zealand can serve as a role model in terms of the stage of political and economic development of such a young country. After all, Aotearoa gained full independence from its metropolis - United Kingdom - only in 1947. It is not without reason that this country ranks every year at the top of the rankings of the most economically developed countries, characterized by the highest standards of living, but also in the forefront of the most convenient places to live and run own business (Write, 2015; Nwokoro, 2021; Best place to start or run a business - New Zealand second only to Singapore; New Zealand 
is best place to do business but UK slips to ninth - report). It is also worth emphasizing that New Zealand constitutes a link between the PICTs in the new international legal trend - the regionalization process. Regionalization, as an institutional development of forming a given region, has become an important element of international law since the 1980s, along with the formation of local international organizations on individual continents. New Zealand's foreign trade policy strongly emphasizes multilateral, regional trade agreements (RTA). It is currently the member of six multilateral RTA, including ASEAN - Australia - New Zealand, Australia - New Zealand Closer Economic Relations Trade Agreement (ANZCERTA), Comprehensive and Progressive Agreement for Trans-Pacific Partnership (CPTPP), Pacific Agreement on Closer Economic Relations Plus (PACER Plus), South Pacific Regional Trade and Economic Cooperation Agreement (SPARTECA), and Trans-Pacific Strategic Economic Partnership. This seems to be a substantial share of the total thirteen New Zealand's free trade agreements in force and one announced (New Zealand. Regional Trade Agreements Database). Such emphasis manifests New Zealand's commitment to regionalism, which is primarily instrumental for the neighbouring Pacific Island countries in their response to global challenges. In particular, Pacific Island countries negotiating their RTA with regional leaders - Australia and New Zealand pressed for agreements that would take account of their unique trading circumstances and arrangements that would allow more Pacific Islanders to work abroad (Morgan, 2018). The joint coordinated and unified actions, both legal and extra judicial, of the Pacific Island states will be more visible and hence considered by global players rather than the individual voices of underdeveloped, poor economies.

The government in Wellington implements the welfare state policy in a broad spectrum (Lawn \& Clarke, 2008). It does so by issuing numerous legal acts, as well as through active participation at the forum of intergovernmental local organizations and fostering 
changes in its own society (Baker, 2015). Indicatively, the RTA negotiations become a platform where enhanced transparency and public participation in drafting foreign trade policy were tested. For example, while negotiating CPTPP, the New Zealand government established a dedicated online platform with information about the agreement and opportunities for businesses and launched series of consultations with stockholders to engage the wider public (Marceddu, 2018, p. 686).

The increasing role of the Maori minority in public life is also not without significance (Mitchell, 2009). The CPTPP negotiations revealed a great interest of the Maori minority to actively draft New Zealand foreign trade policy and busted actions of the indigenous community towards granting their sufficient involvement. For example, over the summer of 2015, Maori individuals, tribes' representatives, and organizations filed nine claims to the Waitangi Tribunal over concerns that the CPTPP might not have conformed with the rights and obligations accorded to Maori by the Treaty of Waitangi (Marceddu, 2018, p. 687). In aggregate, the text of CPTPP in Chapter 29 "Exceptions and General Provisions" includes dedicated Article 29.6 "Treaty of Waitangy", which sets up for New Zealand two main exceptions from CPTPP obligations. Firstly, the free trade obligations under conditions of non-discrimination do not "preclude the adoption by New Zealand of measures it deems necessary to accord more favourable treatment to Maori in respect of matters covered by this Agreement, including in fulfilment of its obligations under the Treaty of Waitangi". Secondly, the interpretation of the Treaty of Waitangi, including the nature of the rights and obligations arising under it, is not a subject of despite settlement under CPTPP.

Therefore, we might assume that the actions of the New Zealand politicians are still an actual response to the high level of awareness of citizens who, using democratic channels, strive for better living and working conditions. 


\section{New Zealand - PRC Free Trade Agreement}

The New Zealand - PRC FTA stands aside from most FTAs in the region due to the differences between contracting parties' economies. While China has a large population, an abundant labour force, and low per capita income, New Zealand has a small population, a scarce labour force, and a high per capita income (Kayani, 2021, p. 889). However, the FTA in question, alongside the markets' opening, shows a long-term impact towards Chinese influence upon New Zealand social life. For example, in the ethnical context, the Islands are inhabited by people of European origin (64\%), Maoris $(16.5 \%)$, Oceania people, but mainly territories that are now or used to be dependent on the Wellington government (8\%) (Central Intelligence Agency, 2021. New Zealand). The only ethnic group that increases every year is the Chinese. And although, according to official data, there are only $5 \%$ of Chinese in the society of almost 5 million people (New Zealand Statistics Office, 2018), the real data is much larger. In Auckland, the country's largest city and its business capital, having population of over 1.5 million, every fourth resident is of Chinese origin (Tan \& Singh, 2015). The Chinese are noticeable as employees in most shops, mainly vegetable and grocery stores, are owners of enterprises, mainly real estate, as well as at universities and higher schools, being the elite of students receiving state scholarships. This is largely a consequence of New Zealand's opening to China, which was formally reflected in the signing of a trade agreement in 2008.

The FTA turned out to be a breakthrough, as Wellington government was the first one among developed Western countries that decided to legally bind itself with the People's Republic of China in order to eliminate numerous economic barriers. The FTA is constantly presented by the New Zealand side as a reason to be proud using terms, such as "success story", "significant trade opportunities" or "a catalyst for closer cooperation" (New Zealand Ministry of Foreign Affairs and Trade, 2018. New Zealand-China 
FTA overview). Certainly, there are visible business evidence how fast the FTA affected bilateral trade. New Zealand goods being exported to China have quadrupled since entering into force of the agreement on 7th April 2008, being signed in Beijing. What is more, China is since then New Zealand's largest trading partner, with two-way trade valued at over NZ Dollars 33 billion only in 2019. What has to be added here, before signing the FTA, the two-ways trade was amounted to only NZ Dollars 9 billion. In addition, China became New Zealand's second largest but also fastest growing tourism market, largest source of international students, as well as a significant source of foreign investments (Ibid.).

Here some basic facts of the FTA have to be enlisted. Tariffs in bilateral trade have been eliminated for over $97 \%$ of New Zealand goods being exported to China. All exports other than dairy (some products remain subject to tariffs until 2024) became eligible for tariff-free access into China. The same goes with all imports from China which were eligible for tariff-free access. The agreement was introduced as the mean aiming at improving access to Chinese markets for New Zealand businesses, service providers and consumers. Faster and easier temporary entry to China was possible due to improved visa processing. Settling disputes on the basis of private international law was in turn made by a clear process embedded in the FTA text. Lastly, New Zealand electrical and electronic equipment products were given a legal way to easier and less costly comply with the Chinese certification requirements (Ibid.).

Now the key facts and numbers need to be given to illustrate the bilateral trade relations. New Zealand exports to China of total NZ Dollars 20.1 billion. It comprises NZ Dollars 16.7 billion in goods and NZ Dollars 3.4 billion in services. New Zealand's major goods exports include dairy (mainly milk powder for children, butter and cheese), meat and wood products, and lastly preparations of cereals, flour and starch. While New Zealand's major services exports include tourism, education, transportation and financial services (New 
Zealand Ministry of Foreign Affairs and Trade, 2019. Key facts on New Zealand-China trade). New Zealand in turn imports from China the total amount of NZ Dollars 13.3 billion, comprising NZ Dollars 12.5 billion in goods and NZ Dollars 800 million in services. New Zealand's major imports from China include electronics, machinery, clothing and furniture (Ibid.).

As if that was not enough, and apparently both sides decided that this was the case, on 26 January 2021, China and New Zealand signed the Protocol to Amend the New Zealand-China Free Trade Agreement. This Protocol was created in order to upgrade the existing free trade pact, but also to secure a better deal for both countries through expanded market access, widened tariff-free schemes, and lastly expedited processes for exporters. Due to the ongoing epidemy of SARS-CoV-2, the Protocol was formalized during the video call between the New Zealand Trade Minister Damien O'Connor and China's Commerce Minister Wang Wentao, after three years of negotiations, started already in 2016 (China Briefing, 2021. China-New Zealand FTA Upgrade: Reduced Costs and Compliance for NZ Exporters). The revision seeks to modernize the FTA provisions to align with the latest trade policies, as well as business practices in the new areas of cooperation: e-commerce, government procurement, environment, and competition. It also removes all remaining tariffs and reduces compliance measures for exporters. Exactly addressing new issues like e-commerce, but also putting an increased focus on environmental issues is seen as indeed innovative. In recent years, China has opened up its services economy to other countries and made commitments in new services sectors not covered in trade with New Zealand. Thus, the biggest aim of the government in Wellington was to upgrade the FTA in order to reflect these commitments and go further, creating new opportunities for New Zealand service suppliers in the China market (New Zealand Ministry of Foreign Affairs and Trade, 2021. New Zealand - China Free Trade Agreement Upgrade). 


\section{New Zealand - Between European and Asian Heritage}

The New Zealand - PRC FTA gives not only economic opportunities or outputs. It does and certainly will even more affect the social and cultural background of the countries, understandably to the high degree in the smallest partner country. When it comes to the civilisation and values, including legal values, it must be underlined that New Zealand has created the most developed economy, embedded in the Western civilisation having European norms in its maritime region of Oceania. In addition, Aotearoa has no natural competitor in the South Pacific, where all PICTs are also connected to the Western civilisation through the process of colonisation and then decolonisation. However, when we add the Commonwealth of Australia (the official name of Australia according to its 1901 Constitution) to Oceania, then the Australian economy outclasses New Zealanders by far. And it is in fact the constant competition with the "big Australian brother" in the so-called the Trans-Tasmanian partnership, named after the Tasman Sea, that separates Australia from New Zealand (Siekiera, 2017). Such hard for the New Zealand competition made New Zealanders to look for another trade partner, from outside the region. China, the second largest economy, has been constantly showing own interests in the Pacific region. Therefore, it seemed to be perfect match for the politicians in Wellington.

New Zealand lies at the meeting point of, at one side the Western (yet European) culture, having the Common law legal order, and on the other side with the Eastern culture with its influences from the Southeast Asia. Due to the geographical location and forced by such proximity close trade contacts within the Asia-Pacific region, the influx of Asians to the Islands is gradually increasing. Here we recall citizens of the People's Republic of China, the Republic of India, the Republic of Korea and the Republic of the Philippines. Already, the percentage of people of Asian origin (mainly Chinese) is over $12 \%$ among the New Zealand population (New Zealand Statistics 
Office, 2015. New Zealand in Profile 2015: An overview of New Zealand's people, economy, and environment).

An interesting fact, which can be given here is the failed forecast of the New Zealand Statistics Office, made on the basis of the 2013 census. The prognosis about the New Zealand future population was saying that by 2021 as much as $33 \%$ of the New Zealanders would be of Chinese origin (New Zealand Statistics Office, 2013. How accurate are population estimates and projections?). However, the lockdown of the country due to the SARS-CoV-2 epidemic in 2020 (from March) and again in 2021 (August) had a huge impact on the cessation of migration and relocation of entrepreneurs' families.

As for the migration law, New Zealand has the most restrictive immigration regime and the most extensive catalogue of visas across the entire system of the Commonwealth of Nations. In order to obtain permission to enter New Zealand, either to work or study, one must meet a long list of legal and material conditions ${ }^{1}$. An issue omitted in the research studies, but in fact very interesting is comes to trade is the New Zealand's strict border control. This is made due to the need for protection of the unique micro-system of the Islands. For instance, in 2015 there was a plague of fruit fly, the spores of which someone brought to New Zealand in fruit, despite the restrictive ban on the import of any food products or any plant or animal products ${ }^{2}$.

Undoubtedly, it was the Immigration Act 1987, then amended by the Immigration Act 2009, which was a milestone in the context of migration to New Zealand. Earlier regulations were based on the so-called principle of preferred countries of origin. Only citizens of selected nations could have been granted a work or student visa, and thus they could have enjoyed a number of privileges. Instead,

\footnotetext{
1 What the author found out personally herself.

2 In addition to that, trekking shoes must be clean, which is also strictly checked at the airports at the border control point in order to prevent the possibility of bringing spores that could destroy New Zealand's endemic species.
} 
the so-called list of "unwanted nations" is still something the government in Wellington is apologising for ${ }^{1}$. Asian nations, mainly the Chinese, were on that list. It should be noted that already at the time of the first migrations to New Zealand, the then British colony, during the gold rush in the $1860 \mathrm{~s}$, Chinese communities began to form enclaves, bringing new family members who could have easily found work in the newly emerging state. It caused a series of cultural conflicts with Europeans (King 2012).

After all, as a very scrupulous and hard-working nation, the Chinese focus on accumulating capital and knowledge through internationally recognized education. This is in absolute contrast to the national traits of New Zealanders who do not display any form of cult of money or education. It is far the most egalitarian society, not oriented towards lucrative careers or need for climbing the steps of promotion. Therefore, it should not be surprising that people of Chinese origin are awarded management positions or university scholarships. As Professor Helena Kaho from the Faculty of Law at the University of Auckland told the author ${ }^{2}$, only a few years ago the Maori was perceived as the privileged nation in both the academic and social spheres. As can be expected, this gives rise to further conflicts, misunderstandings and brings accusations against the Chinese. What has to be added here is that fact that Chinese are accused of falsification documents, work certificates or knowledge of skills. The originality or authenticity of which not so many New Zealanders can tell, neither in public nor private companies. Those stories, widely reported by the media, do not help Chinese community to assimilate within the New Zealand society. On the other hand, though, Chinese prefer to keep aside, in own communities, where

The interview made by the author with Prof. Lech Janczewski, a specialist in the field of security from the Business School of the University of Auckland, 25.02.2015.

2 The interview made by the author with Prof. Helena Kaho, a lecturer at the Faculty of Law of the University of Auckland, 24.02.2015. 
older generations do not even speak English, as everything what they need, work, shops and services are given by compatriots. It is also true that the Mandarin or Cantonese languages are required for most jobs in restaurants or hotels, which is an insurmountable barrier for New Zealanders or other foreigners ${ }^{1}$.

New Zealand's official policy is "One China Policy" - not recognizing Taiwan as an independent entity of international law. However, there are two embassies based in Wellington: Chinese and Taiwanese. This results in many tensions in bilateral relations, including in the field of diplomatic protocol. New Zealand state institutions, universities, and private enterprises seek contacts with their counterparts in China. After all, having a Chinese representative as the main partner of the company and, in the long run, establishing a branch in New Zealand is considered prestigious, as well as an expression of the company's international development. Investment and legal assistance are in turn provided by a number of associations established for this purpose by the state and private hubs themselves. Just a few main providers can be enlisted here: the China Chamber of Commerce in New Zealand, the New Zealand China Trade Association, the New Zealand China Development Group Limited (Open Database Of The Corporate World), the New Zealand ASEAN Business Alliance, and more.

\section{Niu Chiland}

Bearing in mind all the presented facts and numbers, it should be assumed that there will be even more of private and public instruments strengthening bilateral trade relations, but also facilitate migration from China to New Zealand. In 2014, for the first time in New Zealand's history, China was first in the ranking of countries where goods and services are imported, ahead of its closest Trans-

1 The interviews made by the author with Poles and New Zealanders in Auckland, Hamilton, Wellington, Christchurch and other smaller towns during her doctoral studies at the Faculty of Law of the University of Victoria. 
Tasmanian partner - Australia. The Commonwealth of Australia fell to third position, just behind the European Union. Hence, but also as a consequence of these changes, the norms of immigration law had to change in relation to economic reforms, and also to turn New Zealand towards China. Demographic changes are the next inevitable step.

In June 2021, China received 32\% of New Zealand's total exports, the amount as large as never before. The exports included $90 \%$ of $\operatorname{logs}, 44 \%$ dairy, $41 \%$ of meat. While New Zealand economy clearly shows benefits of trade with China, and anyhow sees any potential negative effects, like political dependence from this communist state, for Australia, New Zealand's closest neighbour, is totally different story. The politicians in Canberra and Beijing continue to escalate tensions, mainly in the trade sphere. Australian trade with China in almost all industries has decreased $40 \%$ amid tensions, as reported in March 2021. Thermal coal exports to China were down 70\%, while metallurgical coal had dropped 60\%. Coal exports dropped $83 \%$ when comparing the figures with December 2020 (Lei, 2021).

Such far different approaches by New Zealand and Australia to China can be explained by politics. Australia does see a potential threat which unlimited access to national market for China. Here the economic factors are put after the social change in culture, which might occur when one civilization (Eastern one - Chinese) will try to overwhelm the existing, smaller-in-number one. We cannot forget the Chinese approach to human rights, or rather their official neglecting, where any minorities cannot feel protected, where political opponents are being tortured, kidnapped and killed, where a life of an individual is always less significant than the good of the community, the party - the Communist Party.

Australia and New Zealand do possess diverse understanding of their own position in international community, both globally and regionally. Being a smaller country than Australia, New Zealand is fully aware of own limits, when it comes to potential economic and 
political hegemony in the South Pacific region. In turn Australia, for decades, have been perceived as a natural regional hegemon. In addition, Canberra and Wellington present different strategic priorities, as New Zealander have been focusing on establishing own economic importance in order to provide for people's livelihood, welfare and political stability. The same goes with the bilateral relations with the United States. It is no secret that Australians feel much more connected to the US, while New Zealand was many times in own history presenting largely anty-Washington's policy attitude. The government in Wellington attaches greater importance to the existing trade ties and known markets, thus is unwilling to sacrifice own interests due to the hegemony of the US. Finally, Australia's allies, including New Zealand, have absorbed market share in China that Australia lost in recent years. We could in fact observe strong Australia - New Zealand competition within the Chinese market in many areas (Ibid.). As it was presented in the article, New Zealand's exports of agricultural and livestock products, as well as seafood to China have increased significantly leaving behind Australia.

Finally, the official policy of Canberra is to rely on rising international iron ore prices. It was therefore intentional to allow China - Australia relations to deteriorate. Additionally, Australia has been trying to persuade New Zealand to work with itself again through the Trans-Tasman partnership, for the benefit of those two nations, but at the same time to contain Chinese imperialist's appetite and jointly safeguard the hegemony of the US in the Pacific region. From such a reasoning we might deduce that this whole trade game in not only about the economic growth but mainly about the potential political power and demarcation of the old-new spheres of influence. Australia is aware that for its own interests it is better to keep its closest neighbour, so similar when it comes to culture, history, heritage, politics and legal order, away from the Chinese sphere of influence, far different when it comes to values and norms. 


\section{Conclusions}

New Zealand trade growth with China is being observed especially since singing the Free Association Treaty in 2008. China is since then New Zealand's largest trading partner, with two-way trade valued at over NZ Dollars 33 billion in comparison with only 9 billion before signing the FTA. This close economic cooperation was made at the cost of cutting of closest before brotherly alliance with Australia, New Zealand's "big brother". The government in Canberra is warning Wellington of the hidden intentions of the People's Republic of China, that is does not concert only economic influence, but at the longest phase this unlimited access to the New Zealand market can bring other than Western values and norms. Already now we can observe the pure statistics of the annually increasing amount of the Chinese population in New Zealand. This itself does not pose any potential threat. However, when we consider legal culture and official politics of the Communist Party of China, many political, legal and moral questions may come up. This rhetoric is neglected by the New Zealand side claiming Australians being racists and nationalistic.

New Zealanders are small nation, who managed to establish a welfare state based on the high level of awareness of citizens who, using democratic channels, strive for better living and working conditions. Such values as tolerance, equality, freedom of choice, dignity, human rights and protection of minorities are not obeyed by China. They are, nevertheless, important for the Chinese people migrating to New Zealand, not only to gain the better level of live, but most importantly, to escape from the deadly regime. Here again, one needs to be aware of the difference between the government and the people, who do not always associate themselves with the official policy of the government of the country they were born in or whose parents come from. Therefore, the upcoming decades will be a difficult test for the New Zealand democracy and the rule of law, how New Zealand's politician and ordinary people shall balance 
between the respect of other nationalities, open market and the need for protection of the Western civilisation's values.

\section{REFERENCES}

Baker, N. (2015). New Zealand and Australia in Pacific Regionalism. In G. Fry \& S. Tarte (Eds.). The New Pacific Diplomacy. (pp. 137-148). ANU Press.

Best place to start or run a business - New Zealand second only to Singapore. (2015, December 21). RSM. https://www.rsm.global/newzealand/news/ best-place-start-or-run-business-new-zealand-second-only-singapore

Central Intelligence Agency. (2021, July). New Zealand. https://www.cia.gov/ the-world-factbook/countries/new-zealand/\#people-and-society

China Briefing. (2021, February 11). China-New Zealand FTA Upgrade: Reduced Costs and Compliance for NZ Exporters. https://www.china-briefing.com/ news/china-new-zealand-fta-upgrade-reduced-costs-and-compliance-for-nzexporters

China Chamber of Commerce in New Zealand. http://www.cccnz.org.nz

Kayani, F.N. (2021). China's Mushrooming Free Trade Agreements: New Zealand and China's Upgraded Free Trade Agreement. WSEAS Transactions on Business and Economics, 18, 884-893. DOI: 10.37394/23207.2021.18.84

King, M. (2012). The Penguin History of New Zealand. London.

Lawn, P.A., \& Clarke, M. (2008). Sustainable Welfare in the Asia-Pacific: Studies Using the Genuine Progress Indicator. Bodmin.

Lei, Y. (2021, July 27). NZ trade growth with China should give Australia pause for thought. Global Times. https://www.globaltimes.cn/page/202107/1229776. shtml

Marceddu, M.L. (2018). Implementing Transparency and Public Participation in FTA Negotiations: Are the Times a-Changin'? Journal of International Economic Law, 21, 3, 681-702. DOI:10.1093/jiel/jgy034

Mitchell, L. (2009). Maori and Welfare, A Study of Maori Economic and Social Progress from May 2009.

Morgan, W. (2018). Much lost, little gained? Contemporary trade agreements in the pacific Islands. Journal of Pacific History, 53, 3, 268-2863. DOI: $10.1080 / 00223344.2018 .1475832$

New Zealand ASEAN Business Alliance. https://nzaba.asia/contact 
New Zealand China Trade Association. http://www.nzcta.co.nz/

New Zealand is best place to do business but UK slips to ninth - report. (2018). The Guardian. https://www.theguardian.com/business/2018/oct/31/newzealand-is-best-place-to-do-business-but-uk-slips-to-ninth-report-world-bank

New Zealand Ministry of Foreign Affairs and Trade. (2018). New ZealandChina FTA overview. https://www.mfat.govt.nz/br/trade/free-tradeagreements/free-trade-agreements-in-force/nz-china-free-trade-agreement/ new-zealand-china-fta-overview

New Zealand Ministry of Foreign Affairs and Trade. (2019). Key facts on New Zealand-China trade. https://www.mfat.govt.nz/br/trade/free-tradeagreements/free-trade-agreements-in-force/nz-china-free-trade-agreement/ key-facts-on-new-zealand-china-trade

New Zealand Ministry of Foreign Affairs and Trade. (2021). New Zealand China Free Trade Agreement Upgrade. https://www.mfat.govt.nz/br/trade/ free-trade-agreements/free-trade-agreements-concluded-but-not-in-force/ nz-china-free-trade-agreement-upgrade/overview

New Zealand. Regional Trade Agreements Database. (2021). World Trade Organization. http://rtais.wto.org/UI/PublicMaintainRTAHome.aspx

New Zealand Statistics Office. (2018). https://www.stats.govt.nz/ tools/2018-census-ethnic-group-summaries/chinese

New Zealand Statistics Office. (2013). How accurate are population estimates and projections? An evaluation of Statistics New Zealand population estimates and projections, 1996-2013. https://www.stats.govt.nz/methods/how-accurateare-population-estimates-and-projections based on the unavailable website: http://www.stats.govt.nz/browse_for_stats/population/estimates_and_ projections/subnational-ethnic-population-projections/asian.aspx

New Zealand Statistics Office. (2015, March). New Zealand in Profile 2015: An overview of New Zealand's people, economy, and environment. http://datainfoplus.stats.govt.nz/Item/nz.govt.stats/7079024d-6231-4fc4824f-dd8515d33141?_ga=2.64638887.96830192.1629650570-977847432. 1629650570

Nwokoro, J. (2021). 9 Best Cities in New Zealand to Start a Business. Profitable Venture. https://www.profitableventure.com/cities-new-zealand-start-business

Open Database Of The Corporate World. https:/opencorporates.com/companies/ nz/1194427 based on the formerly existing website http://www.nzcdgroup.com

Parliament of New Zealand. (1987, April 21). Immigration Act (No. 74). http:/www.nzlii.org/nz/legis/hist_act/ia19871987n74165/ 
Parliament of New Zealand. (2009, October 16). Immigration Act (No 51). https://www.legislation.govt.nz/act/public/2009/0051/latest/whole.html

Siekiera, J. (2017). Partnerstwo tasmańskie - zarys relacji Australii z Nową Zelandią [Tasmanian partnership - an outline of Australia's relations with New Zealand]. In A. Kandzia-Poździał, \& J. Siekiera (Eds.). Australia $w X X i X X w$.: Polityka, historia i kultura [Australia in the 20th and 20th Centuries: Politics, History and Culture] (pp. 57-77). WUŚ. [in Polish].

Siekiera, J. (2020). Regional integration in the South Pacific: Challenges for public governance. Brazilian Journal of International Law, 17, 1, 433-442. DOI: 10.5102/RDI.V17I1.6641

Tan, L., \& Singh, H. (2015, March 9). Asian Auckland: How our city has changed - Explore our interactive. NZ Herald. https://www.nzherald.co.nz/ nz/asian-auckland-how-our-city-has-changed-explore-our-interactive/ YZBPN7LM7BI2IJIWIWIYTBADOE/

The State-Parties. (2018, March 8). Comprehensive and Progressive Agreement for Trans-Pacific Partnership (CPTPP). https://www.dfat.gov.au/trade/ agreements/in-force/cptpp/official-documents

Wright, G. (2015, November 12). Best Countries for Doing Business. Global Finance. https://www.gfmag.com/global-data/economic-data/best-countriesdoing-business?page $=1 \#$ axzz2pLxScd9K

Сіекіера Й. УВТ Нової Зеландї з Китаєм: зростання торгівлі на тлі соціальних змін. - Стаття.

Урядом у Веллінгтоні було запроваджено безліч юридичних і комерційних механізмів для полегшення торговельної практики китайських партнерів. Азіатські іммігранти у Новій Зеландії заповнюють реальний пробіл на невеликому ринку праці на Аотеароа, надаючи висококваліфіковану і працелюбну робочу силу. Як наслідок, практично усі сфери соціального та економічного життя Нової Зеландії схильні до змін. Цей феномен нової і досить несподіваної демографічної ситуації отримав прояв у новій назві цієї країни - Niu Chiland. Фактично, єдиною етнічною групою у Новій Зеландії, яка збільшується з кожним роком, є китайці. Хоча за офіційними даними у суспільстві з майже 5 млн осіб лише $5 \%$ китайців, реальні показники $\epsilon$ набагато вищими. В Окленді, найбільшому місті країни і діловій столиці 3 населенням понад 1,5 млн осіб, кожен четвертий мешканець має китайське походження. Угода про вільну торгівлю між Китаєм і Новою Зеландією свого часу стала проривом, оскільки Веллінгтон став першою столицею серед розвинених західних країн, які вирішили юридично зв'язати себе 
торговельними зв'язками з Китайською Народною Республікою у 2008 році. У 2021 р. Китай і Нова Зеландія підписали Протокол про внесення поправок до цієї угоди і додали до неї сфери, що раніше не приймалися до уваги: електронну комерцію і навколишнє середовище. У той час як економіка Нової Зеландії явно демонструє переваги торгівлі з Китаєм і передбачає будь-які потенційні негативні наслідки, такі як політична залежність від цієї комуністичної держави, що не поважає права людини, між політиками у Канберрі і Пекіні триває ескалація напруженості. Австралія, на відміну від Нової Зеландії, намагається стримати апетити китайських імперіалістів і зупинити Пекін, перш ніж відкрити для нього власну сферу інтересів у Тихоокеанському регіоні.

Ключові слова: Нова Зеландія, Китай, торгівля, міжнародна торгівля, китайська міграція, китайська меншість, Тихий океан, південна частина Тихого океану.

\section{Сиекиера Й. ССТ Новой Зеландии с Китаем: рост торговли на фоне социальных изменений. - Статья.}

Правительством в Веллингтоне было введено множество юридических и коммерческих механизмов для облегчения торговой практики китайских партнеров. Азиатские иммигранты в Новой Зеландии заполняют реальный пробел на небольшом рынке труда на Аотеароа, предоставляя высококвалифицированную и трудолюбивую рабочую силу. Как следствие, практически все сферы социальной и экономической жизни Новой Зеландии подвержены изменениям. Этот феномен новой и достаточно неожиданной демографической ситуации отразился в новом названии этой страны - Niu Chiland. Фактически, единственная этническая группа в Новой Зеландии, увеличивающаяся с каждым годом, это китайцы. Хотя по официальным данным в обществе из почти 5 млн человек всего 5\% китайцев, реальные показатели гораздо выше. В Окленде, крупнейшем городе страны и деловой столице с населением более 1,5 млн человек, каждый четвертый житель имеет китайское происхождение. Соглашение о свободной торговле между Китаем и Новой Зеландией в свое время стало прорывом, поскольку Веллингтон стал первой столицей среди развитых западных стран, решивших юридически связать себя торговыми связями с Китайской Народной Республикой в 2008 году. В 2021 г. Китай и Новая Зеландия подписали Протокол о внесении поправок в это соглашение и добавили в него ранее не принимавшиеся во внимание сферы: электронную коммерцию и окружающую среду. В то время как экономика Новой Зеландии явно демонстрирует преимущества торговли с Китаем и предвидит любые потенциальные негативные последствия, такие как политическая зависимость от этого коммунистического 
государства, не уважающего права человека, между политиками в Канберре и Пекине продолжается эскалация напряженности. Австралия, в отличие от Новой Зеландии, пытается сдержать аппетиты китайских империалистов и остановить Пекин, прежде чем открыть для него собственную сферу интересов в Тихоокеанском регионе.

Ключевые слова: Новая Зеландия, Китай, торговля, международная торговля, китайская миграция, китайское меньшинство, Тихий океан, южная часть Тихого океана. 